University of Wollongong

Research Online

Faculty of Science, Medicine and Health -

Papers: part A

Faculty of Science, Medicine and Health

$1-1-2017$

\title{
Geoarchaeological research in the humid tropics: a global perspective
}

Mike W. Morley

University of Wollongong, mmorley@uow.edu.au

Paul Goldberg

University of Wollongong, goldberg@uow.edu.au

Follow this and additional works at: https://ro.uow.edu.au/smhpapers

Part of the Medicine and Health Sciences Commons, and the Social and Behavioral Sciences

Commons

\section{Recommended Citation}

Morley, Mike W. and Goldberg, Paul, "Geoarchaeological research in the humid tropics: a global perspective" (2017). Faculty of Science, Medicine and Health - Papers: part A. 4363.

https://ro.uow.edu.au/smhpapers/4363

Research Online is the open access institutional repository for the University of Wollongong. For further information contact the UOW Library: research-pubs@uow.edu.au 


\title{
Geoarchaeological research in the humid tropics: a global perspective
}

\author{
Abstract \\ Geoarchaeological research is now commonly undertaken as an integral component of archaeological \\ investigations across much of the world. However, in humid tropical regions there is a relative shortfall of \\ this Earth-Science approach to understanding archaeological records. In these regions, where hot and \\ humid conditions prevail for significant parts of the year, sedimentological records are prone to high \\ levels of diagenesis, bioturbation and weathering. This means that understanding and quantifying \\ archaeological site formation processes can be very challenging because we may have not have \\ sufficient existing data with which to decipher the stratigraphic (and microstratigraphic) features recorded \\ in these sequences. In this paper we introduce a special issue of . Journal of Archaeological Science in \\ which we showcase a selection of geoarchaeological research from across the equatorial regions of five \\ continents, highlighting the types of stratigraphic sequences and sedimentological features that are likely \\ to be encountered, and evaluating the tools that can be employed to maximise the geoarchaeological \\ potential of these unique records. Additionally, we use this opportunity to review geoarchaeology in the \\ humid tropics from a global perspective, outlining the main problems that geoarchaeologists face \\ working in these environments and the techniques available to mitigate them. \\ Disciplines \\ Medicine and Health Sciences | Social and Behavioral Sciences

\section{Publication Details} \\ Morley, M. W. \& Goldberg, P. (2017). Geoarchaeological research in the humid tropics: a global \\ perspective. Journal of Archaeological Science, 77 1-9.
}




\title{
1 Geoarchaeological research in the humid tropics: a global
} perspective

Mike W. Morley ${ }^{1}$ and Paul Goldberg ${ }^{1,2}$

${ }^{1}$ Centre for Archaeological Science (CAS), University of Wollongong, Northfields Avenue, Wollongong, NSW, 2500, Australia

2 Institut für Naturwissenschaftliche Archäologie, Eberhard-Karls-Universität Tübingen, Rümelinstrasse 23, 72070 Tübingen, Germany

\begin{abstract}
Geoarchaeological research is now commonly undertaken as an integral component of archaeological investigations across much of the world. However, in humid tropical regions there is a relative shortfall of this Earth-Science approach to understanding archaeological records. In these regions, where hot and humid conditions prevail for significant parts of the year, sedimentological records are prone to high levels of diagenesis, bioturbation and weathering. This means that understanding and quantifying archaeological site formation processes can be very challenging because we may have not have sufficient existing data to decipher the stratigraphic (and microstratigraphic) features recorded in these sequences. In this paper we introduce a special issue of Journal of Archaeological Science in which we showcase a selection of geoarchaeological research from across equatorial regions of five continents, highlighting the types of stratigraphic sequences and sedimentological features that are likely to be encountered, and evaluating the tools that can be employed to maximise the geoarchaeological potential of these unique records. Additionally, we use this opportunity to review geoarchaeology in the humid tropics from a global perspective, outlining the main problems that geoarchaeologists face working in these environments and the techniques available to mitigate them.
\end{abstract}

\section{Introduction: geoarchaeology in the humid tropics}

The environments of the humid tropics are unique, posing major challenges for both archaeologists working in these regions today, and the human populations that have inhabited these climatic zones on and off over the past 200,000 years or so. These hot and humid environments are unforgiving testing grounds for geoarchaeologists working to interpret cultural and sedimentary records as they are wholly unconducive to the preservation of a wide range of archaeologically important materials (e.g. bone, organics, biomarkers, minerals such as calcium carbonate). However, geoarchaeological science is in a perfect position to tackle the problem of reconstructing archaeological site formation processes that are likely to be specific to these humid tropical environments. The remit of geoarchaeological science is wide-ranging and multi-disciplinary, but here we boil it down to crystallize two primary goals: i) the multi-scalar reconstruction of past environments with which human populations have interacted, and ii) the identification and evaluation of processes that form and preserve an archaeological site. Both of these goals are pertinent in interpreting the archaeological record of humid tropical environments, 
as well as the sedimentary matrix from which this cultural information is recovered.

This special issue of Journal of Archaeological Science showcases a wide range-both chronologically and geographically-of geoarchaeological research from the fascinating and often demanding environments of the humid tropics and adjacent sub-tropical, climatically transitional zones. What draws this collection of papers together is the ever more apparent need to assess the modes and tempo of site formation processes in these environments, and how they differ-if at all-from those recorded in non-tropical or arid tropical regions, both of which have received much attention in the archaeological and geoarchaeological literature (see e.g. Goldberg and Macphail, 2006, and references therein). As such, regionally specific mechanisms of sedimentation need to be carefully assessed along with the geoarchaeological signatures that characterise these atypical and often extreme environments. The research featured in this volume provides valuable insights into a range of these issues, highlighting the depositional and post-depositional environments that are likely to be encountered, and the methods that can best be employed to identify diagnostic signatures and mitigate for the often-aggressive degradation processes operating in humid tropical regions.

The humid tropics cover a significant proportion of the Earth's terrestrial surface (Tricart, 1972; Thomas, 1974), including areas that are particularly important in our understanding of human evolution and the rise and fall of early civilizations (e.g. equatorial Africa, Southeast Asia, South America). However, despite the ubiquity of these wet, tropical landscapes we know surprisingly little about the geomorphological processes and mechanisms that have shaped them and continue to do so (Gupta, 1993, 2011). As one of the primary goals of geoarchaeology is to reconstruct the environmental conditions under which archaeological sites are formed, modified and preserved, site formation processes operating in the humid tropics are therefore similarly poorly understood (Kourampas et al., 2009; Morley, in press). The research presented in this volume has a wide-ranging global relevance, originating from the tropical (and in some cases marginal sub-tropical) regions of five continents: South America (Brazil), North America (Belize), Africa (Tanzania and Malawi), Asia (Myanmar, Malaysian Borneo, Flores and Timor Leste), and Australasia (Papua New Guinea and Northwest Australia). What links these spatially disparate regions are the hot and humid climates that prevail today, and that have done so on and off throughout the Quaternary (Douglas and Spencer, 1985). The linking theme of these studies, outside of the site-specific research questions that they address, is the reconstruction of the depositional and postdepositional histories of the sites using state-of-the-art geoarchaeological science techniques applied to stratigraphic sequences.

The initial impetus that sparked the inception of this volume was provided by the positive feedback and fruitful discussions that followed a paper presented by one of us (MWM) on this topic at the Australian Archaeology Association's (AAA) 2014 annual meeting in Cairns, in the tropical Australian north. It became apparent then that geoarchaeologists working in tropical northern Australia and Southeast Asia 
91 felt that they were working with sedimentological records without sufficient

92 comparable analogues available in the relatively copious published

93 geoarchaeological literature, generated primarily from supra-humid tropical regions

94 (e.g. temperate Europe and North America; semi-arid Southern Africa; arid to hyper-

95 arid Southwest Asia). The general feeling was that whilst archaeological sites (and

96 cultural material) located in the wet tropics were exposed to an unusually vigorous

97

98

99

100

101

102

103

104

105

106

107

108

109

110

111

112

113

114

115

116

117

118

\section{The papers: a selection of geoarchaeological research from the humid tropical regions of the world} combination of the elements characteristic of these harsh environments, there was not a concerted drive to assess the potentially atypical site formation processes at work, and the diagnostic signatures that might help recognise these physical and chemical environments. Despite some of the most important archaeological stories of the present day-understanding the global dispersal of Homo sapiens; reconstructing the early civilizations of the Americas; elucidating the origins of agriculture outside SW Asia, to name just three-bringing these regions into focus, we currently have limited understanding about how these environments might influence the archaeological record, and the potential limitations of techniques at the geoarchaeologist's disposal.

Nonetheless, there are some exceptions to this general rule. Over the past few decades a small number of geoarchaeologists and archaeological scientists have endeavoured to reconstruct archaeological site formation processes in humid tropical environments (e.g. Glover, 1979; Gillieson 1986; Mercader, 2002; Mercader et al., 2003; Gilbertson et al., 2005; Stephens et al., 2005; Lewis, 2007; Araujo et al., 2008; Kourampas et al., 2009, 2015; Mijares and Lewis, 2009; Rabett et al., 2011, 2016). Whilst this list is not exhaustive, by no means would a more comprehensive catalogue be significantly weightier. We hope that this special issue not only expands on this relatively slender body of work, but also stimulates further discussion and helps focus research agendas in this field over the coming years and decades.

In presenting the papers that form this volume, it seems appropriate to set them out geographically, and we have done this by traversing from the far west (relative to the Europe-centric Mercator map projection), from South and Central America (Villagran et al., in press and Macphail et al., in press, respectively), through to Africa (Sulas et al., in press and Wright et al., in press), and on to Asia (Morley, in press, Marwick et al., in press, Stephens et al., in press, Morley et al., in press, and O'Connor et al., in press), before finally moving into Australasia (Denham and Grono, in press and Vannieuwenhuyse et al., in press) (Figure 1).

We would like to note that there are important chronological and geographical gaps in this selection of papers. The timing of volumes such as these is rarely perfect, and there are regions in which contributions would have been welcome, but the timing of projects and publication schedules simply did not synchronise. We do not claim 
134 that these papers span all of the areas in which humid tropical geoarchaeological 135 research is being undertaken, and regions under-represented (e.g. Northwest South 136 America, Equatorial Africa, South Asia) in this volume, therefore, do not reflect a 137 shortfall of research occurring there, but more our lack of space to publish them or the asynchrony of publication schedules.

We start our tour of the humid tropics in central Brazil, where Villagran and colleagues investigate early Holocene sediments from Lapa do Santo-a rockshelter rich in human remains associated with complex funerary practices. Through the combination of micromorphology, $\mu \mathrm{FTIR}$, and organic petrology, they identify both in situ hearths and reworked combustion products (most likely relating to housekeeping), shedding new light on the complexity of these practices and the identification of features diagnostic to specific activities. These results are bolstered by the use of experimental work, using observation from heating modern day soils and sediments. Interestingly, they also identify the use of termite mound fragments, possibly as part of the combustion process serving as heat retainers. The close association of the intense fire-use to the human graves shows multi-functional zones of the cave, with combustion by-products being excavated to make way for interments. They were also able to identify clay aggregates that are likely pedogenic material inwashed from outside the site, potentially linking the external geomorphic system with the internal karst system. This study highlights the use of multiple datasets to address questions of both site formation and human activities occurring at a site, a recurring theme in the volume and justly so.

Moving north to Belize, Central America, Macphail et al. (in press) investigate sediments at the Mayan site, Marco Gonzalez, using micromorphology and other geochemical and sedimentological techniques to identify a type of Dark Earth that differs from the intensively-studied Amazonian Dark Earths (ADE's, or terra preta). The recognition of these anthropogenically-enhanced soils in a Mayan context raises interesting questions about localised human-driven environmental change, both contemporary with the occupation of the site, and contributing to the soil characteristics today. They utilise a range of chemical, physical and mineral magnetic datasets to strengthen their interpretation of the stratigraphy, revealing a series of ground raising deposits that they associate with over 500 years of industrial activity (salt production), prepared floor construction, and the accumulation of both industrial and domestic waste. Magnetic susceptibility measurements proved especially useful in revealing strong tropical weathering. Interestingly, in terms of catchment-wide environmental change, they show that the site was latterly covered with a layer of beach sand relating to a marine incursion, ultimately reclaimed and sealed with a lime plaster floor. The multi-parameter approach employed by the authors highlights the utility of using a number of lines of evidence to robustly recreate past environmental and chemical conditions, and disentangle both anthropogenic and natural site formation processes.

Across the Atlantic, and on east coast of Africa, Sulas et al. (in press) examine a late Holocene, tropical urban environment on the Swahili coast using a suite of analytical 
180 techniques. They employ micromorphology alongside geochemical and magnetic 181 analyses of soils and sediments to answer questions about the use of functional 182 activity zones in the Swahili stone-town, Songo Mnara, Tanzania. They show that 183 geochemical characterisation using ICP-AES enabled them to identify localised use 184 of functional space, including recognising the use of both roofed and unroofed 185 spaces. The development of these geochemical techniques has ramifications for identifying activity zones in other areas where structures may be too ephemeral for recognition by standard archaeological techniques. The successful use of this approach in tropical environments-where enhanced heat and humidity can accelerate diagenetic processes-reveals the utility and strength of geochemical datasets when allied with fine-resolution microstratigraphic analyses.

Moving inland to the west—and back in time to the Middle Stone Age (MSA)— Wright and colleagues investigate an archaeological landscape in the humid subtropics of Malawi. Given that the lion's share of our knowledge concerning human prehistory is derived from archaeological and palaeoenvironmental material recovered from cave and rockshelter sites, this paper attempts to redress the balance, and focus in on the landscape to build a clearer picture on how MSA populations interacted with the dynamic environments in which they lived. Adopting a truly multi-scalar approach, they show that the main phase of occupation of their study area coincided with a relatively dry phase, when the alluvial fan on which hominin activity took place was aggrading slowly, most likely allowing for incipient soils to develop on stable surfaces. It is well known that environments in the humid tropics and sub-tropics are not conducive for the preservation of nonlithic archaeological material, and the authors note this problem in their work, citing heat, humidity, bioturbation and intense weathering as serving to blur the archaeological and sedimentological record. Ultimately, they are able to reconstruct diachronic landscape changes, and link these to archaeological activity, through the use of multiple lines of evidence utilising geoarchaeological and archaeological datasets.

Heading eastwards into the extensive humid tropical landscapes of Southeast Asia, we begin with a review by Morley (in press) on the use of geoarchaeology as a tool for assessing the completeness of the archaeological and palaeoanthropological record of Late Pleistocene human colonisation of the region. Ever since the pioneering work of Eugene Dubois in the mid-19 ${ }^{\text {th }}$ century (e.g. Dubois, 1896), Southeast Asia has been a critical region in our understanding of modern and archaic human dispersal outside of Africa. However, given that much of the region experiences very hot and humid environmental conditions, there needs to be a concerted effort to qualify how archaeological site formation processes operate in these environments. Morley (in press) explores how geoarchaeological science is currently employed in the region, and how an increase in this approach might fill gaps in our understanding of human dispersals, and bolster claims of important fossil finds that have in the past suffered from stratigraphic uncertainties. In this review paper the author proposes a plan of action to increase the use of geoarchaeological approaches in the region, especially important given that we have 
such a poor understanding of how geomorphological systems work in the humid tropics.

The first of four case studies from Southeast Asia, Marwick et al. (in press) report on a Late Pleistocene/Holocene record from Khao Toh Chong rockshelter, Thailand, Mainland Southeast Asia (MSEA). The coastal region of Krabi, in which the rockshelter is located, lends itself to the study of human interactions, with often rapid changes in sea level associated with the Pleistocene-Holocene transition and the mid-Holocene highstand. Using a suite of physical, geochemical and magnetic properties, the authors explore the ability of these data to assess stratigraphic integrity and to provide local and site-wide environmental context to the extensive faunal, shell and stone tool record from the site. They use these datasets to address one of the grand challenges in archaeology today: to understand the processes driving the switch from a foraging economy to one that is reliant on agriculture. The relative deficiency of the archaeological record at this key juncture in the reorganisation of food production in the region leads the authors to employ a geoarchaeological approach to analysing the environmental context of the rich archaeological record from the site. In this way they strive to disentangle the drivers behind this shift, and attempt to compare natural changes in the environment with these cultural reconfigurations. Using bulk sediment parameters (mineral magnetic and grain size) coupled with carbon isotope, XRD and ICP-AES analysis, they show that the sediments at the site are undisturbed and are delivered from a single continuous source, aiding in the reconstruction of the depositional history of the site. This study is important given the significant dataset available from the site that elucidates cultural and technological change during this understudied chronological period.

Moving down into Island Southeast Asia, onto the Sunda Shelf, Stephens et al. (in press) present a micromorphological study of sediments from Niah Cave, Malaysian Borneo, building on previous work at the site (Stephens et al., 2005). The study uses micromorphology to identify evidence of post-depositional modification of the archaeological sediments, especially important in humid, tropical environments where diagenesis can be severe and have polygenetic origins. As with many sedimentological records from the region, they find that guano played a significant role in the formation and subsequent modification of the site, with recognised populations of insectivorous bat populations providing a highly acidic environment in which elements of the deposits and archaeology can be degraded or removed. The authors highlight a raft of potential geomorphological processes that they show influenced the formation of the Niah Cave stratigraphy, all of which are commonly encountered in humid tropical environments. These include weathering and illuviation of fines, diagenetic alteration of minerogenic and biological inclusions, bioturbation, and the slumping of saturated sediments. These examples serve to highlight the challenges that exist for geoarchaeologists working in the region. That these processes were identified in the microstratigraphic record emphasises the capacity of microstratigraphic analyses in reconstructing the depositional and postdepositional history of a site. 
273 Heading east into Wallacea, the region of Island Southeast Asia where islands retain their insular status even during the lowest sea levels of the Pleistocene, Morley et al. (in press) present the first micromorphological results from Liang Bua, Flores, the cave from which the only known bones of Homo floresiensis have been recovered (e.g. Morwood et al., 2004). The paper focuses on an area of the site not previously studied, which fills a known $\sim 25$ ka gap in the chronology caused by a major erosional event occurring in the area of the cave where the hominin fossils were found (Sutikna et al., 2016). Using micromorphology and vibrational spectroscopy (FTIR and Raman) they identify three periods of major environmental change at the site, likely linked to changes in regional climate. They claim that major shifts in sediment characteristics relate to the alternating activation and deactivation of the karst hydrogeological system, connecting the rear of the site to a source of water ingress via cracks and fissures in the bedrock. Evidence for post-depositional alteration of the sediments includes a severely phosphatised flowstone, indicating marked diachronic changes in chemical environments in the cave. Notably, they also present evidence for the use of fire at the site from $\sim 41-24 \mathrm{ka}$, with in-situ fireplaces and reworked combustion bi-products, which they associate with modern human activity at the site. This is important as it significantly narrows the time gap between the last appearance of $H$. floresiensis ( $\sim 50 \mathrm{ka})$ and the first appearance of Homo sapiens on Flores.

Moving further east into Wallacea, and onto the Sahul Shelf, research by O'Connor et al. (in press) at cave sites on Timor Leste and Papua New Guinea provides some interesting insights about commonly occurring cave breccias, which often form useful relationships with archaeological material. A suite of new radiocarbon dates from the three caves reveal useful information about the mechanisms responsible for the removal of deposits, and the potential this has for creating large chronological hiatus' within sedimentary and archaeological records. The authors conclude that these sediment removal events do not coincide with changes in regional precipitation, instead invoking catchment or site-level shifts in the hydrological system. On a broader note, they note that stratigraphic sequences formed in caves in humid tropical regions are extremely complex, potentially more so than those found in other climatic regions owing to the cycle of cut and fill events related to the switching on and off of monsoon system, an observation also made by Morley and colleagues in this volume.

The final two papers in the volume keep us firmly on the Sahul Shelf. Denham and Grono (in press) present research from Papua New Guinea, in the north of this large continental landmass. Kuk Swamp is an internationally important archaeological site that has yielded important information about the transition to early farming practices in the region, dating as far back as 7,000 cal BP. They use a multiparameter approach to assess the shallow sedimentary sequence preserved at the site, and investigate the utility of geoarchaeological methods to investigate cultivation practices and isolate these from natural pedogenic processes. Their work highlights the need for complimentary techniques applied to the study of sediment 
sequences, mapping both physical and chemical spatial characteristics, to fully

319 evaluate signals diagnostic of natural (pedogenic) processes or anthropogenic

320 (agricultural) practices. Denham and Grono's (in press) study again highlights the

321 small number of studies that focus on humid tropical environments, demonstrated

322

323

324

325

326

327

328

329

330

331

332

333

334

335

336

337

338

339

340

341

342 by the dearth of modern analogue sediments outside of temperate NW Europe and semi-arid Southwest Asia to use as a yard-stick for their interesting results.

Moving south to the Kimberley region of northwestern Australia, Vannieuwenhuyse et al. (in press) examine two archaeological sites that straddle semi-arid and tropical monsoonal climatic zones, placing them in a marginal area that is particularly sensitive to monsoon dynamics. Using micromorphological analysis allied with traditional sedimentological techniques, they study sequences that extend back as far as 45 ka (Carpenter's Gap 1) and 34 ka (Carpenter's Gap 3), revealing a suite of microstratigraphic features associated with changes in site environment that they link to major shifts in regional climate. They detect marked variations in humidity that they correlate with the switching on and off of monsoon influence at the two sites. The micromorphological work also helps identify periods of human activity at the sites, allowing for insights into human-environment interactions in this marginal zone. Importantly, their work shows that we cannot invoke environmental change as the primary driver behind the occupation of Australian cave and rockshelter sites. At present, mirroring the situation in nearby Southeast Asia, high-resolution geoarchaeological work is rarely undertaken in Australia, and this paper really makes an important and convincing step along the path of employing Earth-Science approaches to understanding the use of cave and rockshelter sites, and the mechanisms driving changes in population dynamics.

\section{The problems: interpreting archaeological records in humid tropical environments}

Working in the humid tropics can be a physical and intellectual challenge as we still do not fully appreciate how many tropical landscapes form and evolve, and at what tempo, and we do not have a full appreciation of how sediments are transported, and by which mechanisms (Gupta, 1993, 2011). This has ramifications for geoarchaeologists, whose job (fundamentally, at least) is to determine how an archaeological site has formed, and assess to what degree the site has been modified or preserved (Goldberg and Macpahil, 2006; Gilbert, 2016). At present we have not generated sufficient geoarchaeological data from the humid tropics to be confident in the recognition of biological and chemical signatures specific to these exceptional environments (Morley, in press). An examination of the papers that constitute this volume show that a number of crosscutting themes and recurring issues are evident that are either specific to the humid tropics, or at least are significantly accelerated or catalysed in these chemically active environments. At best, these issues can generate a level of uncertainty that makes it difficult to assess its completeness or degree of preservation, and at worst seriously jeopardise accurate interpretations of the archaeological record. The benefit of thematic volumes such as this special issue 
361 is the opportunity that is afforded of appraising a collection of papers in a single

362 monograph, allowing for recurring problems to be identified and ultimately

363 mitigated against.

\section{$364 \quad 3.1 \quad$ Enhanced biological activity in the humid tropics}

365 Humid tropical regions are biologically rich, and so the disturbance, truncation,

366 modification and destruction of archaeological sequences in these environments by

367 biological mechanisms is commonplace (e.g. Gillieson, 1986; Gilbertson et al., 2005;

368 Lenoble et al., 2006; Kourampas et al., 2009). These destructive processes fall into

369 two broad categories: physical and chemical. Bat and bird guano is often recorded in

370 archaeological contexts in non-tropical regions (e.g. Karkanas et al., 2002; Shahack-

371 Gross et al., 2004), but in the humid tropics these deposits can be exceptionally thick

372 and well developed, significantly reducing the $\mathrm{pH}$ of percolating water (Gilbertson et

373 al., 2005; Bird et al., 2007; Wurster et al., 2010). Guano-driven diagenesis can

374 significantly modify sedimentological and archaeological records, introducing bias

375 and uncertainty into the interpretation of assemblages of biological material (e.g.

376 faunal record) (Karkanas et al., 2002). At Niah Cave, (Stephens et al., 2005, in press)

377

378

379

380

381

382

383

384

385

386

387

388

389

390

391

392

393

394

395

396

397

398

399

400

401

402

403 we have seen that guano is exceptionally common and has played a significant role in the formation and subsequent preservation of the archaeological record. At Liang Bua, Morley et al. (in press) have indirectly inferred the presence of guano by the analysis of diagnostic chemical signatures left imprinted on elements of the stratigraphy. It is clear that the recognition of guano, whether directly or indirectly, is absolutely critical in reconstructing the depositional and post-depositional history of cave and rockshelter sites, especially important in understanding Pleistocene archaeological records, the majority of which are found in these depositional environments. Furthermore, stable isotope compositional analyses of guano reveal the utility of these deposits as diachronic archives of palaeoenvironmental change (e.g. Bird et al., 2007).

Physical bioturbation of sediment sequences through the action of floral (e.g. root action) or faunal (e.g. burrowing) agency is likewise a problem that is exacerbated in biologically productive environments associated with elevated moisture and temperature levels (O'Connor et al., 2010). Cave fauna can burrow into sediment layers creating large and/or complex galleries (Stephens et al., in press; Vannieuwenhuyse et al., in press), and these can be filled with material that postdates the original layer, creating problems for both the stratigraphic integrity of finds and geochronological age estimates. The mixing and homogenisation of archaeologically important sediments and soils due to these activities can fundamentally affect the recognition, interpretation and dating of archaeological assemblages (e.g. Denham and Grono, in press). Deep and extensive root systems can cause a great deal of disturbance to archaeological sites (Vannieuwenhuyse et al., in press), and this can have an impact on various components of the research, including the geochronological program (e.g. vertical movement of datable material, such as sand-sized quartz grains). If these disturbances are not observable at the 
404 macroscopic level, micromorphological analyses can provide unequivocal evidence

405 for faunal bioturbation in the form of infilled gallery voids and insect granules.

406

407

408

409

410

411

412

413

414

415

416

417

418

419

420

421

422

423

424

425

426

427

428

429

430

431

432

433

434

435

436

437

438

439

440

441

442

443

444

445

446

447

\subsection{Monsoon system dynamics and the effect of seasonal rain on archaeological sites}

The northward and southward migration of monsoon fronts can have a marked consequence on the diachronic interaction of an archaeological site with percolating or running water (Hope et al., 2004; Westaway et al., 2007; Kourampas et al., 2009; Wurster et al., 2010), a potential source of both erosion and as a catalyst for chemical reactions. It should be borne in mind that the humid tropics of today may not have been so throughout the climatic oscillations of the Quaternary (e.g. Bird et al., 2005). In fact, these regions may have experienced periodic temperate or even semi-arid climate regimes during glacial cycles of the Pleistocene. The study of sites located in climatically marginal zones-relative to migrating monsoon frontsaffords not only insights into the adaptability (or not) of modern humans inhabiting these environments, but also allows for the geoarchaeological assessment of sediment sequences that have been subject to alternating cycles of higher and lower water flux to the site (Kourampas et al., 2009; Morley et al., in press).

Vannieuwenhuyse and colleague's examination of rockshelter sequences in the Kimberly region of Northwest Australia (in press) exemplifies research from a study area that straddles two climatic envelopes-tropical monsoon and arid environments-thus making it particularly sensitive to migrations of the Indonesian-Australian monsoon system (Bird et al., 2004; Reeves et al., 2013). It is because of this marginal location that the site experienced periodic shifts to more arid conditions over the Last Glacial Maximum (LGM) period as the deserts in this area expanded (Vannieuwenhuyse et al., in press). Wright et al. (in press) also report from a climatically marginal region in Malawi, Africa, where marked fluctuations in the presence of groundwater and the process of de-watering (and concomitant volume reduction) at the site can be correlated with long-term monsoon system dynamics. The high seasonal rainfall that they infer from the sedimentological and microstratigraphic record coincides with a depauperate faunal record and an absence of archaeological features such as hearths that might normally have been preserved. In Thailand, Marwick et al.(in press) record changes in monsoon seasonality that they see reflected in the archaeological record as shifts in food procurement strategies.

The erosive action of water, including saturation-induced mudflows and mass movements, can have a major detrimental effect on the preservation of archaeologically important sediment sequences (Gillieson, 1986; Stephens et al., 2005, in press; Dykes, 2007; Sutikna et al., 2016). In caves this can relate to reconfigurations of the karst hydrological system, which might be linked to shifts in Quaternary climate (e.g. shift to more humid conditions), tectonic activity (e.g. earthquakes), or internal geomorphological processes (e.g. fissures blocked by carbonate precipitation). On the island of Flores, Indonesia, Morley et al. (in press) 
record alternating suites of sediment packages that appear to be switch between wet and dry deposition in response to changes in the internal hydrology of the cave, which they correlate with regional speloethem records marking northward and southward migration of the ITCZ. This alternating input of water to the site is the probable driver behind marked erosive events caused by water flowing through the site, as well as increased chemical diagenesis recorded in some parts of the sequence. Douglas and Spencer (1985) claim that the greatest erosional effect will occur during monsoon transitional periods, from dry to wet, at which time physical erosion by falling rain has the chance to erode bare soils/sediments during the lag time before which vegetation takes hold again. This is likely to be the same over longer, millennial timescales, such as the warming limb of a glacial-interglacial transition.

\subsection{Diagenetic and taphonomic processes}

461 Water is the prime mover in catalysing chemical processes (Thomas, 1974), so the combination of high temperatures and the presence of groundwater can have a profound effect on the preservation of archaeological sequences. Chemical diagenesis is significantly promoted in hot and wet climatic regimes, and this can affect the preservation of both organic and inorganic archaeological material (Weiner et al., 2002; Stephens et al., 2005; Lewis, 2007; Kourampas et al., 2009). Geoarchaeological analytical techniques seek to identify signatures diagnostic of these diagenetic processes, using high-resolution optical or geochemical analyses to recognise bi-products of chemical reactions, such as authigenic mineral production or the alteration of components of the stratigraphy (Karkanas et al., 2000; Weiner et al., 2002; Mcadams, 2016). The weathering and partial dissolution of limestone clasts can serve as a useful indicator of the level of diagenesis that a sediment sequence has undergone, and such evidence is commonly observed in humid tropical environments (Stephens et al., in press). The presence of authigenic minerals, such as gypsum, can reveal much about the environments of deposition in which they formed. In the Kimberley region of northwest Australia, for example, Vannieuwenhuyse et al. (in press) record repeated instances of gypsum, which they link to the rapid evaporation of percolating groundwater, potentially catalysed by the presence of other sources of calcium such as anthropogenic ashes.

The mobilisation and precipitation of readily dissolved and transported minerals, such as calcium carbonate, in suspension can complicate taphonomic considerations of archaeological horizons, for example through the formation of calcite breccias and associated 'false floors' ( 0 'Connor et al., in press). The durability of these calcite formations (which can include both natural and archaeological material) can confound straightforward stratigraphic relationships as removal and resedimentation of more recent material can result in younger material having a physical stratigraphic relationship beneath older remnants of calcite-cemented sediment (e.g. Liu et al., 2010). Taphonomic pathways and chronological assessments of material can also be confused given potentially long residence times within breccias before liberation into younger sediments. It should be noted that 
492

493

494

495

496

497

498

499

500

501

502

503

504

505

506

507

508

509

510

511

512

513

514

515

516

517

518

519

520

521

522

523

524

525

526

527

528

529

530

531

532

533

534

535

even thick layers of dense calcite can undergo complete diagenetic modification, as recorded in the phosphatisation of the well-formed calcite flowstone at Liang Bua, Flores (Morley et al., in press). However, the dissolution of archaeologically important material, such as bone and ash, might be buffered if the background $\mathrm{pH}$ is sufficiently high and alkaline conditions persist, such as recorded at Lapa do Santo by Villagran and co-workers (in press).

\subsection{Weathering profiles and soil forming processes in the humid tropics}

Given that both temperature and precipitation are important factors in the development of a soil (Young, 1980), the heat and humidity experienced across much of the tropics has a significant effect on the degree of pedogenic processes. Whereas the rate of weathering in drier tropical regions is quite slow, dominated by physical attrition, the humid tropics are associated with deep weathering profiles and soils (Gupta, 2011). Tropical soils are often thick and well developed, a function of intense and deep weathering profile and the high acidity levels experienced in tropical humus, giving rise to characteristic oxisols (Aruajo et al., 2008; Gupta, 2011). Microorganisms present in soils produce carbonic acid that drives the dissolution of carbonate rocks, a process relevant to archaeological narratives given that caves and rockshelters form primarily in these rock types. Heavy weathering profiles and deep laterite (ferricrete) and oxisol development is a humid tropical phenomena, producing often severely indurated (particularly at or near surface) substrates rich in oxides such as iron and aluminium (Faniran and Lee, 1983).

Thick soil cover and intense weathering are phenomena that have implications for the recognition and interpretation of archaeological sites. Open sites may be interred beneath thick suites of soil and regolith, and stratigraphic sequences may be blurred and homogenised by the action of weathering and pedogenesis. The development of humid tropical soils is a topic tackled by Denham and Grono (in press) (Papua New Guinea; PNG) and Macphail et al. (in press) (Belize). In PNG, the recognition of cultivated soils holds the potential for identifying anthropogenic modification of the landscape linked to the domestication of plants. Identifying and discriminating between sediments and soils is absolutely key in these circumstances, and Denham and Grono (in press) use microstratigraphic techniques to analyse the structure of sedimentary units collected from Kuk Swamp, features that would otherwise be invisible to the naked eye. The type and frequency of characteristic pedofeatures recorded in thin sections allowed them to recognise overprinting of soil horizons and show that these palaeosols are likely the result of more than one soil forming period. In Belize, Macphail et al. (in press) use a range of geoarchaeological techniques to identify cultivatable soils in a Mayan context. Again, micromorphology is used to tackle these questions, and ultimately to demonstrate that the soils at the Mayan site of Marco Gonzalez are distinct from the Amazonian Dark Earths (ADEs) recognised in South America. These anthropogenic soils, enriched by the Mayans populating the site, are evidence that past human activity can have profound effects on the present-day characteristics of a soil, essentially promoting their productivity. 
As mentioned above, it is important to understand karstic processes operating in the humid tropics given the propensity for archaeological sites (caves and rockshelters) to form within carbonate rocks. Faniran and Jeje (1983) state that due to the high quantities of organic material available coupled with high levels of microbial action, "soil water is very aggressive in the humid tropics" (1983: 324), causing high levels of carbonic acid to be released by soil microorganisms. On tropical islands, where a reef limestone nucleus is often at the heart of an island, much thinner soils are likely to develop. At Songo Mnara, shallow terra rossa soils are prevalent due to the very pure reef limestone platform on which they form (Sulas et al., in press), somewhat in contrast to thick oxisol and laterite development in many humid tropical environments.

555

556

557

558

559

560

561

562

563

564

565

566

567

568

569

570

571

572

573

574

575

576

577

578 554 in humid tropical environments.

The problems outlined above that geoarchaeologists must confront when conducting research in the humid tropics are not insurmountable, and increased collaboration between scientists working in these regions will no doubt continue to elucidate the mechanisms and processes. The research featured in this volume tackles these issues head on, with the aim of stimulating geoarchaeological research

\section{The solutions: state-of-the-art methods employed to interpret humid tropical archaeological records}

An important outcome of this special issue has been to showcase the growing number of analytical techniques currently available to the geoarchaeologist with which to reconstruct past environmental conditions and the life history of an archaeological site (Morley, in press). Moreover, multi-disciplinary datasets can allow for a much greater degree of confidence to be placed in palaeoenvironmental reconstructions and assessments of archaeological site formation and degradation. Geoarchaeological science is gradually moving into a new era, where the use of novel, cutting-edge techniques and increased collaboration and integration with other scientists and datasets (e.g. palaeoenvironmental) is enabling geoarchaeologists to interpret archaeological sites with a greater degree of accuracy. A key development in the progress of the discipline in this regard has been the ability to undertake various analyses at the same micro-scale, potentially (and preferably) on the same micromorphological thin sections (and therefore the same intact portion of an archaeological site), thus preserving physical associations and increasing the ability to directly correlate and integrate a wide range of analytical data, ultimately including sedimentological, microstratigraphic, geochemical and geochronological analyses (although we are some way off at present in terms of integrating all of these techniques).

What is notable is that eight of the eleven papers that form this volume use microstratigraphic analyses (micromorphology) to help interpret the sedimentary archives under examination (Goldberg and Aldeias, 2016). The microscopic analyses 
of deposits not only document the composition, texture, and porosity, for example,

580 but as importantly, the geometrical relationships of these components (i.e. fabric).

581 Together, they can reveal much about the formation, preservation and alteration

582 that a sediment sequence has been exposed to since deposition-information that

583

584

585

586 often cannot be discerned at the macroscopic (field) level (Goldberg and Berna, 2010). The technique can also illuminate the types of human activities being carried out at a site, providing information about the lifeways of past inhabitants. Three and a half decades of the use of this technique to explore archaeological sequences

587 (Goldberg and Aldeias, 2016) has seen this sub-discipline grow from a small niche

588

589

590

591

592

593

594

595

596

597

598

599

600

601

602

603

604

605

606

607

608

609

610

611 technique to a one that is used much more routinely to tackle a wide range of archaeological questions and challenges.

Advances in scientific techniques that allow for highly spatially-resolved analyses of in situ sedimentary arrangements ('microarchaeology'; Weiner, 2010) now means that the analysis of micromorphological thin sections is not restricted solely to optical analysis using standard polarising microscopy techniques. Spectroscopic analyses using Fourier Transform Infrared (FTIR) or Raman vibrational spectroscopy, and on-site techniques such as $\mu$-FTIR and pXRF (Mentzer, 2014) opens up the possibility for a geoarchaeologist to obtain quantitative geochemical and mineralogical data from microfacies already identified during micromorphological analysis. Villagran et al. (in press) employs $\mu$ FTIR analysis to analyse thin sections from Lapo do Santa, enabling a number of inferences to be made including estimates of temperature attained in archaeological fires and the degree of thermal alteration of archaeological sediments. Morley et al. (in press) use vibrational spectroscopy (FTIR and Raman) to bolster optical analyses of diagenetic modification of a calcite flowstone, and the microscope and imaging functionality of this apparatus allows for the spatial analysis of thin sections and the targeting of microfacies recognised during standard optical analysis.

612

613

614

615

616

617

618

619 Scanning electron microscopes (SEMs) and Electron Probe Micro-Analyzers (EPMA) fitted with analytical tools such as Energy-Dispersive X-ray Spectroscopy (EDS), including QEMSCAN, and Wavelength-Dispersive X-ray Spectroscopy (WDS) can also be used to geochemically characterise thin sections of archaeological sediment to the elemental level with a very high degree of spatial resolution (e.g. Mentzer, 2014; Mentzer and Quade, 2012). Macphail et al. (in press) use SEM/EDS analytical tools to differentiate soil types and infer past industrial activities at a Mayan site, and to investigate how these soil types influence present day soil characteristics in the region. Inductively Coupled Plasma-Atomic Emission Spectrometry (ICP-AES) has been shown by Sulas et al. (in press) to be very instructive. They use the technique to identify functional zones within an urban archaeological site,

620 recognised by characteristic chemical signatures relating to specific archaeological activities at the site. 


\section{The future: geoarchaeological research in the humid tropics}

622

623

624

625

626

627

628

629

630

631

632

633

634

635

636

637

638

639

640

641

642

643

644

645

646

647

648

649

650

651

652

653

654

655

656

657

658

659

660

661

662

663

664

665

What geoarchaeologists working in hot and wet regions of Earth must endeavour to achieve over the next decade and moving into the future is to adapt the 'geoarchaeology manual' that has been written over the past three decades of so by geoarchaeologists working in temperate, arid and hyper-arid regions, and produce a revised edition that takes into account the relatively atypical geomorphological processes of the humid tropics. In regions outside of the humid tropics, depositional environments and processes of sedimentation are generally well explicated as scientists are increasingly familiar with the diagnostic chemical and sedimentological signatures that relate to specific environments of deposition and human activities. The point here is that we do not know how much of the existing geoarchaeology vade mecum will be applicable when studying geomorphological landforms, archaeological sites, and stratigraphic sequences located in humid tropical environments. It is likely to be a revision of what we know rather than a complete re-write as initial signs show that the processes are similar, but perhaps accelerated in hot and wet environments. In 1972, the French geomorphologist, Jean Tricart claimed that our "knowledge of the morphogenic characteristics of the humid tropics...remains insufficient, in spite of certain pioneer works...that are too few in number" 1972: xv). Although this number has grown to some extent since then (e.g. Thomas, 1974; Faniran and Jeje, 1983; Douglas and Spencer, 1985; Gupta, 2011), there still remains "... a limited understanding of the geomorphic processes, landforms and sediment in the tropics" (Gupta, 2011: 3). There needs to be a concerted drive by geoarchaeologists working in these environments to advance the science and, perhaps most importantly, to pool their knowledge and analytical expertise concerning the preservation-or not—of archaeological records in the humid tropics.

The collection of papers that form this volume, and the practices and problems this research highlights, only really scratch the surface of the work that is being undertaken in humid tropical environments today, encompassing a wide range of chronological periods and archaeological topics. What we have ventured to achieve here is to present a representative sample of this research-from the Mayans of Central America, to the 'Hobbits' of Flores, through to some of the earliest Australians-to provide examples of the broad spectrum of problems that working in these environments can throw up. By doing this we have showcased the techniques and practices employed by geoarchaeologists to circumvent these difficulties, with the ultimate aim of producing robust environmental and depositional reconstructions with which to contextualize and evaluate archaeological narratives.

The humid tropics are challenging environments to work in, both in terms of conducting research and interpreting palaeoenvironmental datasets, but the rewards are great. Many of the great archaeological questions of today are posed against a humid tropical backdrop. Thus, steps need to be taken to ensure that high quality geoarchaeological research is undertaken more routinely in these regions, 
666 but also - and possibly even more importantly - that geoarchaeologists share their

667 knowledge and the data generated working in these environments, so that robust

668

669

670

671

672

673

674

675

676

677

678

679

680

681

682

683

684

685

686

687

688

689

690

691

692

693

694

695 datasets and reference collections of characteristic features specific to these environments can be developed. We hope that this volume will serve to drive forward this process, highlighting the need for geoarchaeologists to step forward as key players in tropical geomorphological and archaeological research.

It is our intent that this special issue not only advances geoarchaeological research in these unique climatic zones, but also underscores the difficulties encountered working in these environments, and how we might overcome or mitigate these challenges. Similar problems can be encountered elsewhere in other climate zones, but what we have seen is that the modes and tempo of archaeological site formation processes are more pronounced and often accelerated in these environments.

Readers will clearly see that there are significant problems and features specific to tropical geoarchaeology that are much more strongly expressed in these hot and wet environments than other, already well understood, climatic zones. This needs to be taken into account in the future, and we hope that this volume will encourage people to work in these interesting environments that are largely understudied to date.

\section{Acknowledgements}

We would like to thank Robin Torrence for her enthusiasm and exceptional editorial advice during the preparation of this volume. We extend our appreciation to various colleagues at the Centre of Archaeological Science (CAS), University of Wollongong, for pertinent discussions along the way. In particular we thank Bert Roberts for providing the fertile academic environment in which to undertake this endeavour, and the Australian Research Council (ARC) for providing the funding support (Australian Laureate Fellowship [FL130100116] to Richard 'Bert' Roberts, the University of Wollongong). Finally we thank our geoarchaeologist colleagues across the world for insights and inspiration: 'In Lutum, Veritas'.

\section{References}

697

698

699

700

701

702

703

704

705

706

707

708
Araujo, A. G., Feathers, J. K., Arroyo-Kalin, M., \& Tizuka, M. M. (2008). Lapa das Boleiras rockshelter: stratigraphy and formation processes at a Paleoamerican site in Central Brazil. Journal of Archaeological Science, 35(12), 3186-3202.

Bird, M. I., Hope, G., \& Taylor, D. (2004). Populating PEP II: the dispersal of humans and agriculture through Austral-Asia and Oceania. Quaternary International, $118,145-163$.

Bird, M. I., Taylor, D., \& Hunt, C. (2005). Palaeoenvironments of insular Southeast Asia during the Last Glacial Period: a savanna corridor in Sundaland?. Quaternary Science Reviews, 24 (20), 2228-2242. 
Bird, M. I., Boobyer, E. M., Bryant, C., Lewis, H. A., Paz, V., \& Stephens, W. E. (2007). A long record of environmental change from bat guano deposits in Makangit Cave, Palawan, Philippines. Earth and Environmental Science Transactions of the Royal Society of Edinburgh, 98 (01), 59-69.

Denham, T., \& Grono, E. (2016). Sediments or soils? Multi-scale geoarchaeological investigations of stratigraphy and early cultivation practices at Kuk Swamp, highlands of Papua New Guinea. Journal of Archaeological Science. (in review).

Douglas, I., \& Spencer, T. (1985). Environmental change and tropical geomorphology. London: Unwin.

Dubois, E. (1896). On Pithecanthropus erectus: a transitional form between man and the apes. The Journal of the Anthropological Institute of Great Britain and Ireland, 25, 240-255.

Dykes, A. P. (2007). Mass movements in cave sediments: investigation of a 40,000year-old guano mudflow inside the entrance of the Great Cave of Niah, Sarawak, Borneo. Landslides, 4(3), 279-290.

Faniran, A., \& Jeje, L. K. (1983). Humid tropical geomorphology. New York: Longman.

Gilbert, A. S. (Ed.) (2016) Encyclopedia of Geoaechaeology (Encyclopedia of Earth Science Series, 2017 Edition). New York: Springer.

Gilbertson, D., Bird, M., Hunt, C., McLaren, S., Banda, R. M., Pyatt, B., Rose, J., \& Stephens, M. (2005). Past human activity and geomorphological change in a guano-rich tropical cave mouth: initial interpretations of the Late Quaternary succession in the Great Cave of Niah, Sarawak. Asian Perspectives, 16-41.

Gillieson, D. (1986). Cave sedimentation in the New Guinea highlands. Earth Surface Processes and Landforms, 11(5), 533-543.

Goldberg, P., \& Macphail, R. I. (2008). Practical and Theoretical Geoarchaeology. Blackwell publishing.

Goldberg, P., \& Berna, F. (2010). Micromorphology and context. Quaternary International, 214(1), 56-62.

Goldberg, P., \& Aldeias, V. (2016). Why does (archaeological) micromorphology have such little traction in (geo) archaeology?. Archaeological and Anthropological Sciences, 1-10.

753 
754

755

756

757

758

759

760

761

762

763

764

765

766

767

768

769

770

771

772

773

774

775

776

777

778

779

780

781

782

783

784

785

786

787

788

789

790

791

792

793

794

795

796

797

798

799

Glover, I. C. (1979). The effects of sink action on archaeological deposits in caves: an Indonesian example. World Archaeology, 10 (3), 302-317.

Gupta, A. (1993). The changing geomorphology of the humid tropics. Geomorphology, 7(1-3), 165-186.

Gupta, A. (2011). Tropical geomorphology. Cambridge: Cambridge University Press.

Hope, G., Kershaw, A.P., Van Der Kaars, S., Xiangjun, S., Liew, P.M., Heusser, L.E., Takahara, H., McGlone, M., Miyoshi, N. \& Moss, P.T. (2004). History of vegetation and habitat change in the Austral-Asian region. Quaternary International, 118, 103-126.

Karkanas, P., Bar-Yosef, O., Goldberg, P., \& Weiner, S. (2000). Diagenesis in prehistoric caves: the use of minerals that form in situ to assess the completeness of the archaeological record. Journal of Archaeological Science, 27(10), 915-929.

Karkanas, P., Rigaud, J. P., Simek, J. F., Albert, R. M., \& Weiner, S. (2002). Ash bones and guano: a study of the minerals and phytoliths in the sediments of Grotte XVI, Dordogne, France. Journal of Archaeological Science, 29(7), 721-732.

Köppen, W. (1923). Die Klimate der Erde: Grundriss der Klimakunde. Walter de Gruyter \& Company.

Kourampas, N., Simpson, I. A., Perera, N., Deraniyagala, S. U., \& Wijeyapala, W. H. (2009). Rockshelter sedimentation in a dynamic tropical landscape: Late Pleistocene-Early Holocene archaeological deposits in Kitulgala Beli-lena, southwestern Sri Lanka. Geoarchaeology, 24(6), 677-714.

Kourampas, N., Shipton, C., Mills, W., Tibesasa, R., Horton, H., Horton, M., \& Picornell, L. (2015). Late Quaternary speleogenesis and landscape evolution in a tropical carbonate island: Pango la Kuumbi (Kuumbi Cave), Zanzibar. International Journal of Speleology, 44(3), 293.

Lewis, H. (2007). Preliminary soil micromorphology studies of landscape and occupation history at Tabon Cave, Palawan, Philippines. Geoarchaeology-An International Journal. 22(7), 685.

Liu, W., Jin, C. Z., Zhang, Y. Q., Cai, Y. J., Xing, S., Wu, X. J., \& An, Z. S. (2010). Human remains from Zhirendong, South China, and modern human emergence in East Asia. Proceedings of the National Academy of Sciences, 107(45), 1920119206.

Macphail, R. I., Graham, E., Crowther, J., \& Turner, S. (2016). Marco Gonzalez, Ambergris Caye, Belize: A geoarchaeological record of ground raising

Page 18 of 22 
800

801

802

803

804

805

806

807

808

809

810

811

812

813

814

815

816

817

818

819

820

821

822

823

824

825

826

827

828

829

830

831

832

833

834

835

836

837

838

839

840

841

842

843

844

associated with surface soil formation and the presence of a Dark Earth. Journal of Archaeological Science. (online, in press)

Marwick, B., Van Vlack, H., Conrad, C., Shoocongdej, R., Thongcharoenchaikit, C., Kwak, S. (2016). Adaptations to sea level change and transitions to agriculture at Khao Toh Chong rockshelter, Peninsula Thailand. Journal of Archaeological Science. (in review).

Mcadams, C. (2016). Towards a deeper understanding of diagenetic processes in the caves of the humid topics. Geoarchaeology Research Group: Bridging Science and the Humanities, 26 May, 2016. Australian National University, Canberra.

Mentzer, S. M. (2014). Microarchaeological approaches to the identification and interpretation of combustion features in prehistoric archaeological sites. Journal of Archaeological Method and Theory, 21(3), 616-668.

Mentzer, S. M., \& Quade, J. (2013). Compositional and isotopic analytical methods in archaeological micromorphology. Geoarchaeology, 28(1), 87-97.

Mercader, J. (2002). Under the canopy: the archaeology of tropical rain forests. Rutgers: University Press.

Mercader, J., Martı, R., González, I. J., Sánchez, A., \& Garcıa, P. (2003). Archaeological site formation in rain forests: insights from the Ituri rock shelters, Congo. Journal of Archaeological Science, 30(1), 45-65.

Mijares, A. S. B., \& Lewis, H. A. (2009). Cave sites in northeastern Luzon, Philippines: A preliminary soil micromorphological study. Asian Perspectives, 48(1), 98118.

Morley, M. W. (2016). The Geoarchaeology of Hominin Dispersals to and from Tropical Southeast Asia: A Review and Prognosis for the Future. Journal of Archaeological Science. (in review).

Morley, M. W., Goldberg, P., Sutikna, T., Tocheri, M. W., Prinsloo, L. C., Jatmiko, Saptomo, E. W., Wasisto, S., \& Roberts, R. G. (2016). Initial micromorphological results from Liang Bua, Flores (Indonesia): Site formation processes and hominin activities at the type locality of Homo floresiensis. Journal of Archaeological Science. (in press).

Morwood, M.J, Soejono, R.P., Roberts, R.G., Sutikna, T., Turney, C.S.M., Westaway, K.E., Rink, W.J., Zhao, J.X., van den Bergh, G.D., Due, R.A., Hobbs, D.R., Moore, M.W., Bird, M.I., and Fifield, L.K. (2004). Archaeology and age of a new hominin from Flores in eastern Indonesia. Nature, 431:1087-1091. 
845

846

847

848

849

850

851

852

853

854

855

856

857

858

859

860

861

862

863

864

865

866

867

868

869

870

871

872

873

874

875

876

877

878

879

880

881

882

883

884

885

886

887

888

889

890

O'Connor, S., Barham, A., Spriggs, M., Veth, P., Aplin, K., \& St Pierre, E. (2010). Cave archaeology and sampling issues in the tropics: a case study from Lene Hara Cave, a 42,000 year old occupation site in East Timor, Island Southeast Asia. Australian Archaeology, 71(1), 29-40.

O'Connor, S., Barham, A., Aplin, K. \& Maloney, T. (2016). Cave stratigraphies and cave breccias: Implications for sediment accumulation and removal models and interpreting the record of human occupation. Journal of Archaeological Science. (online, in press).

Rabett, R., Appleby, J., Blyth, A., Farr, L., Gallou, A., Griffiths, T., Hawkes, J., Marcus, D., Marlow, L., Morley, M. W., Tân, N. C., Son, N. V. (2011). Inland shell midden siteformation: Investigation into a late Pleistocene to early Holocene midden from Tràng An, Northern Vietnam. Quaternary International, 239(1), 153-169.

Rabett, R., Ludgate, N., Stimpson, C., Hill, E., Hunt, C., Ceron, J., Farr, L., Morley, M., Reynolds, T., Zukswert, H. and Simpson, D. (2016). Tropical limestone forest resilience and late Pleistocene foraging during MIS-2 in the Tràng An massif, Vietnam. Quaternary International. (online, in press).

Reeves, J.M., Barrows, T.T., Cohen, T.J., Kiem, A.S., Bostock, H.C., Fitzsimmons, K.E., Jansen, J.D., Kemp, J., Krause, C., Petherick, L. \& Phipps, S.J., (2013). Climate variability over the last 35,000 years recorded in marine and terrestrial archives in the Australian region: an OZ-INTIMATE compilation. Quaternary Science Reviews, 74, 21-34.

Shahack-Gross, R., Berna, F., Karkanas, P., \& Weiner, S. (2004). Bat guano and preservation of archaeological remains in cave sites. Journal of Archaeological Science, 31(9), 1259-1272.

Stephens, M., Rose, J., Gilbertson, D. D., \& Canti, M. G. (2005). Micromorphology of Cave Sediments in the Humid Tropics: Niah Cave, Sarawak. Asian Perspectives 44(1), 42-55. University of Hawaii Press.

Stephens, M., Rose, J., \& Gilbertson, D. D. (2016). Post-depositional alteration of humid tropical cave sediments: Micromorphological research in the Great Cave of Niah, Sarawak, Borneo. Journal of Archaeological Science. (online, in press).

Sulas, F., Fleisher, J., \& Wynne-Jones, S. (2016). Geoarchaeology of urban space in tropical island environments: Songo Mnara, Tanzania. Journal of Archaeological Science. (online, in press).

Sutikna, T., Tocheri, M. W., Morwood, M. J., Saptomo, E. W., Jatmiko, Due, R. A., Wasisto, S., Westaway, K. E., Aubert, M., Li, B., Zhao, J.-x., Storey, M., Alloway, B. V., Morley, M. W., Meijer, H. J. M., van den Bergh, G. D., Grün, R., Dosseto, A., 
891

892

893

894

895

896

897

898

899

900

901

902

903

904

905

906

907

908

909

910

911

912

913

914

915

916

917

918

919

920

921

922

923

924

925

926

927

928

929

930

931

932

Brumm, A., Jungers, W. L., Roberts, R. G. (2016). Revised stratigraphy and chronology for Homo floresiensis at Liang Bua in Indonesia. Nature. 532: 366369.

Thomas, M. F. (1974). Tropical geomorphology. London: Macmillan.

Tricart, J. (1972). Landforms of the humid tropics, forests and savannahs. London: Longman.

Vannieuwenhuyse, D., O'Connor, S., \& Balme, J. (2016). Settling in Sahul: Investigating environmental and human history interactions through micromorphological analyses in tropical semi-arid north-west Australia. Journal of Archaeological Science (online, in press).

Villagran, X. S., Strauss, A., Miller, C., Ligouis, B., Oliviera, R. (2016). Buried in ashes: site formation processes at Lapa do Santo rockshelter, east-central Brazil. Journal of Archaeological Science. (in review).

Weiner, S. (2010). Microarchaeology: beyond the visible archaeological record. Cambridge University Press.

Weiner, S., Goldberg, P., \& Bar-Yosef, O. (2002) Three-dimensional distribution of minerals in the sediments of Hayonim Cave, Israel: Diagenetic processes and archaeological implications. Journal of Archaeological Science, 29, 1289-1308.

Westaway, K. E., Zhao, J. X., Roberts, R. G., Chivas, A. R., Morwood, M. J., \& Sutikna, T. (2007). Initial speleothem results from western Flores and eastern Java, Indonesia: were climate changes from 47 to 5 ka responsible for the extinction of Homo floresiensis?. Journal of Quaternary Science, 22(5), 429438.

Wurster, C. M., Bird, M. I., Bull, I. D., Creed, F., Bryant, C., Dungait, J. A., \& Paz, V. (2010). Forest contraction in north equatorial Southeast Asia during the Last Glacial Period. Proceedings of the National Academy of Sciences, 107(35), 15508-15511.

Wright, D. K., Thompson, J. C., Schilt, F., Cohen, A. S., Choi, J. H., Mercader, J., ... \& Welling, M. (2016). Approaches to Middle Stone Age landscape archaeology in tropical Africa. Journal of Archaeological Science. (online, in press).

Young, A. (1980). Tropical soils and soil survey (Vol. 9). CUP Archive. 


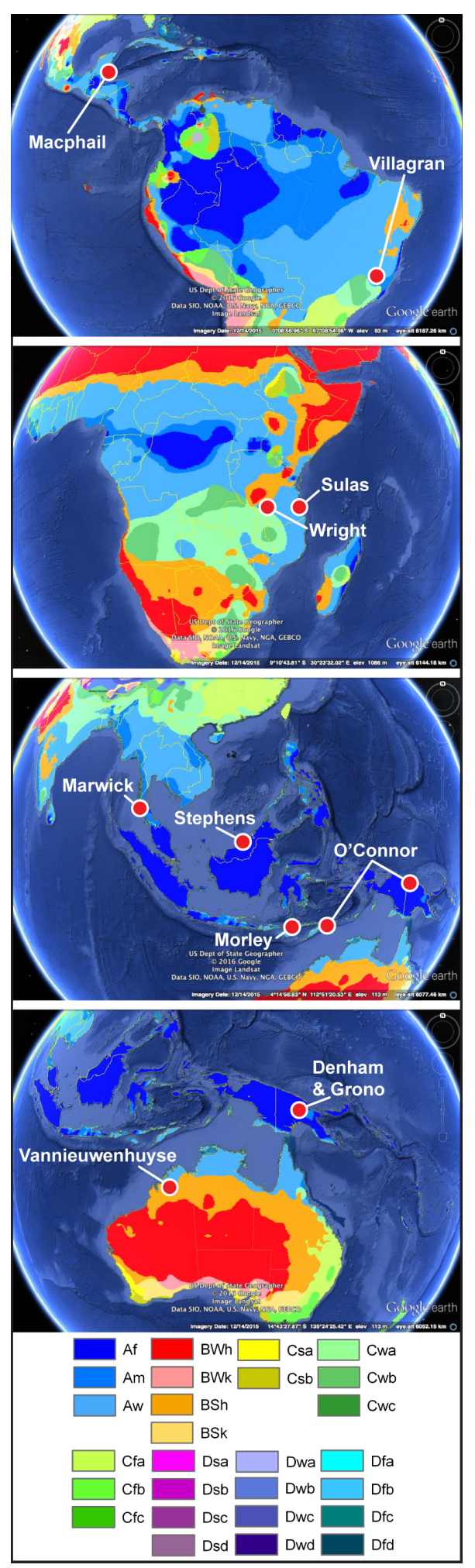

Figure 1: Location maps of the study areas referred to in each of the papers in this volume, from the far west (The Americas) at top, to the far east (Australasia) at base. GoogleEarth images use mapping layers from Peel et al. (2007), an updated version of Köppen's (1923) climate classification system. Legend description: A: equatorial, wet; B: dry, arid; C: warm 938 temperate; D: continental; E: polar (not shown). 